\title{
THE IMPACT OF THE EQUITY CAPITAL AND TRADE CREDIT FINANCIAL SOURCES ON THE COMPANY'S PERFORMANCES SUSTAINABILITY
}

\author{
Dragan Milosevićl, Jovanka Popović2, Jelena Avakumović3, Goran Kvrgić ${ }^{4}$ \\ *Corresponding authorE-mail:dragan.milosevic@famns.edu.rs.
}

A R T I C LE IN F O

Original Article

Received: 19 February 2020

Accepted: 19 May 2020

doi:10.5937/ekoPolj2003735M

UDC 33.067.22:347.728

\section{Keywords:}

agribusiness, trade credit, equity capital, financial conditions, SMEs, performance sustainability

JEL: Q13, Q14, G3, Q56

\begin{abstract}
A B S T R A C T
The crucial aspect of mobilizing financial sources and savings to SMEs in the agribusiness sector and its supply chains towards sustainability and productive investment is of the most importance, what has motivated the research of this paper. Key findings of exploring the impact of two external sources of finance, trade credit and equity capital on the sustainability of the enterprises, are based on the literature review and the empirical research provided in Serbia in 2019. The positive influence of the researched sources of the financing as well as the conditions of this financing on the sustainability of these enterprises is confirmed. The contribution of the research results can be seen in the further improvement of the financial market framework for development of the external sources of finance, trade credit and equity capital in the context of entrepreneurial finance.
\end{abstract}

(C) 2020 EA. All rights reserved.

1 Dragan Milosević, Ph.D., Associate Professor, Faculty of Management, University UnionNikola Tesla, Belgrade, Njegoševa 1a, 21205 Sremski Karlovci, Serbia, Phone: +381 63 287 123, E-mail: dmilosevic321@gmail.com;dragan.milosevic@famns.edu.rs, ORCID ID (https://orcid.org/0000-0002-5979-2562)

2 Jovanka Popović, Ph.D., Assistant Professor, Faculty of Management, University UnionNikola Tesla, Belgrade, Njegoševa 1a, 21205 Sremski Karlovci, Serbia, Phone: +381 64 13455 12, E-mail: jovanka.popovic@famns.edu.rs, ORCID (ID https://orcid.org/00000003-0263-0295)

3 Jelena Avakumović, Ph.D., Assistant Professor, Faculty of Management, University UnionNikola Tesla, Belgrade, Njegoševa 1a, 21205 Sremski Karlovci, Serbia, Phone: +381 69 4775447, E-mail: jelena.avakumovic@famns.edu.rs, ORCID ID (https://orcid.org/00000002-7856-8064)

4 Goran Kvrgić, Ph.D., Full Professor, Faculty of Management, University Union- Nikola Tesla, Belgrade, Njegoševa 1a, 21205 Sremski Karlovci, Serbia, Phone: +381 658099899 , E-mail: goran.kvrgic@famns.edu.rs, ORCID ID (https://orcid.org/0000-0002-1261-4590) 


\section{Introduction}

The organization of agricultural production and services, with a defined time agenda for the transformation of the inputs, commodity market flexibility, the uncertain nature makes problems, if the financial environment support is not following the specific needs of the sector activities. (Walker, 1991; Ahmed, 1989).

SMEs and entrepreneurs in Serbia see the lack of capital for their sustainability and development as one of the main obstacles (Rajan \& Zingales, 2003; Petersen \& Rajan, 1995), what is more obvious in the agribusiness sector.

This should therefore influence both the availability and demand for different types of external funding for SMEs in the agribusiness sector and rural entrepreneurs.

In the European Union, the needs of SMEs for equity financing and trade credit had increased, 33\% of them applied for trade credit, Figure (1). Trade credit has been a relevant type of financing in the last three years: 2016, 2017 and 2018, followed by equity capital, debt securities and other internal funds.

Figure 1. The relevance of types of financing for enterprises in the EU28 in 2016, 2017 and 2018.

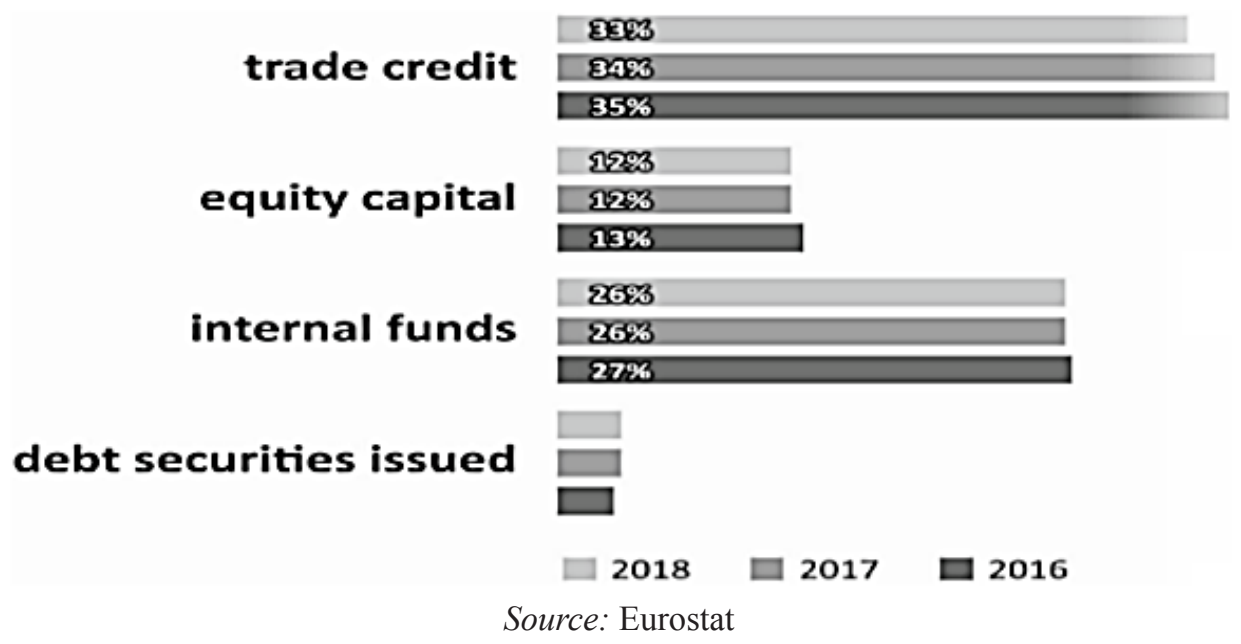

According to Eurostat data for 2018 the retained earnings or sale assets were used by firms in some SEE countries as Croatia, 22\%, in Bosnia and Herzegovina, 25\% in last 6 months in 2018, in comparison with Serbia, with $15 \%$.

Trade credit is used less in these three countries in 2018 in comparison with EU firms (from 4 to 6\%), debt securities are used at the same level, as well as the equity capital (Figure 2). 
Figure 2. The use of trade credit and equity capital in 2018 by the enterprises in Serbia in comparison with Bosnia and Herzegovina.

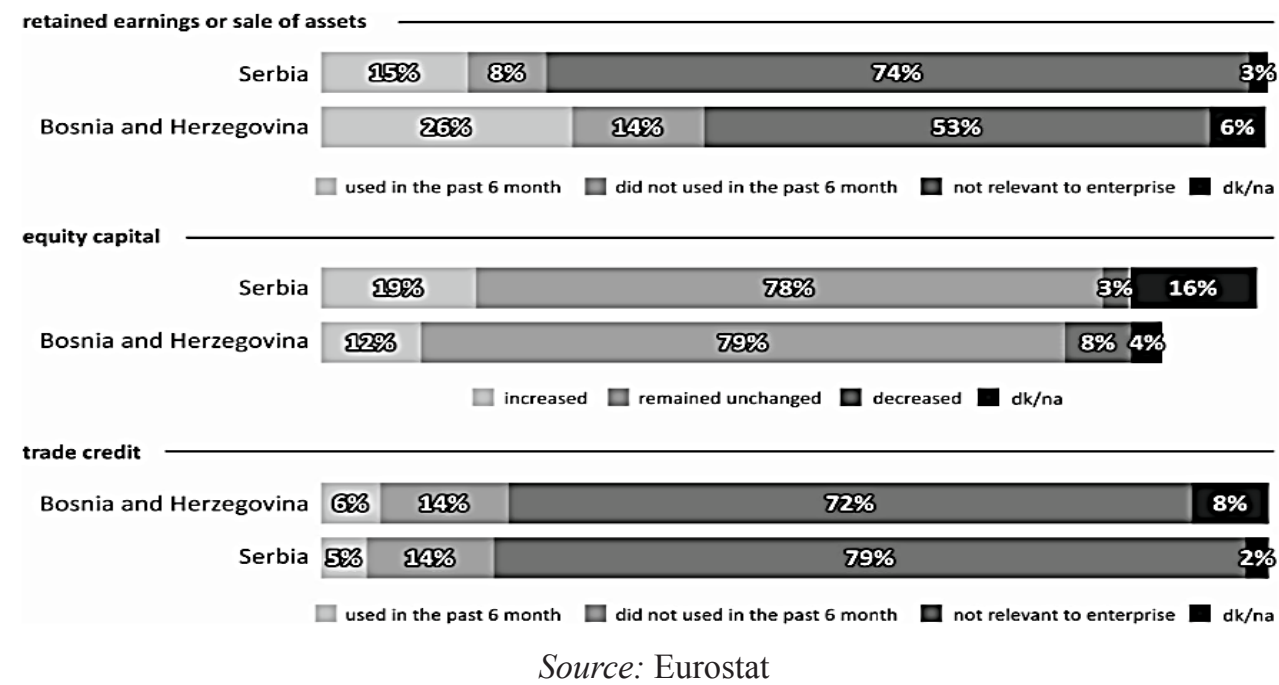

In formulating the research subject the issues of the equity financing and trade credit as external sources of financing are identified, as well as the legal and business circumstances, from a legal institutional perspective; formal contracts, bankruptcy laws to define and enforced property rights.

In financial markets, scholars have argued that stronger legal (minority) shareholder rights, liability rules, and requirements for information disclosure, have favored the development of strong public equity markets. It also hence stimulated firms to use these markets as a funding channel, but the SMEs in agribusiness sector often rely on private equity, which is heavily dependent on well-developed public markets for liquidity and exit (Bowles, 2003).

Owing to this greater supply and hence lower cost of outside equity, the SMEs will tend to be more in favor of raising (private) equity capital in less developed financial institutional framework, like it is in Serbian case (Băncescu et al., 2019). That has motivated the authors of the paper to research the practice of the Serbian SMEs in the agribusiness sector on the usage of these two external sources of finance in the sustaining their business (More \& Basu, 2013; Meltzer, 1960).

The research results a presented so that, after the Abstract with the key aim of the research, the Introduction with some trends in the sector financing is given, and the Theoretical framework on the financial sources is presented. The section with the Methods and materials presents the dataset of the empirical research, the range of variables, the findings and discussion and testing approach. The paper concludes with an elaboration of the implications of the results of the research to the rural financial market development in Serbia. 


\section{Theoretical framework}

Farms, entrepreneurs and SMEs in agrobusiness, together with logistics and trade firms in the supply chain are considered one of the core engine for future growth in Serbia. However, to fulfill this potential, SMEs and rural entrepreneurs need a sustained supply of long-term funding (Clive, Srinivasan \& Udry, 1997; Conning \& Udry, 2005), can be described as fragmented (Diamond 1996; Besley, 1994). SMEs, however, tend to excessively rely on internal and short-term financing sources (Schmidt-Eisenlohr, 2013; Ramey, 1992)

In theory and practice, short-term financing has been established as not suitable for supporting SMEs making long-term corporate investments, in sustaining their innovation programs, and in achieving consistent growth ( $\mathrm{Wu}, 2001)$. This has led policy makers to encourage SMEs to take greater advantage of long-term financing, trade and equity sources (Smith, 1980; Myers \& Rajan, 1998; Myers, 1977).

In the equity financing firm characteristics, including industry composition, firm size, ownership type, and growth rates determine SME willingness to take on equity finance and their attitudes towards this form of finance.

The constraints in the availability of equity finance are a major determinant of use by SMEs. Equity financing is known to be particularly important for SMEs with high growth potential. For SMEs, equity financing normally includes greater involvement of the financing provider in the firm compared to the bank lending that SMEs rely on as their main form of long-term financing (Garcia-Teruel \& Martinez-Solano, 2007; Hart \& Moore, 1991; Hawawini, Viallet \& Vora, 1986).

Equity providers, primarily invest in the future potential of the firm and as partial owners have an interest in, and some control over, how this value is created. The forms of equity financing that SMEs more often access is private equity investments, because the equity investors, for example, might differ with the SME on the strategic direction of the firm and seek to impose their own vision. This close relationship and the associated risks are likely to place trust at the center of SME attitudes towards equity providers. Trust in this case can be taken to mean SME confidence that equity investors will perform their role in a manner that is not detrimental to the firm as nonfinancial factors, vital in determining SME attitudes to financing choices.

Formal institutional development, such as the financial system, the legal system, or regulatory quality, determine rules for accountability and liability in financial transactions has been posited as one important cross-country explanation in this regard (Madestam, 2013). Researchers drawing on cultural relativity theory have built on the profitability gaps in formal institution studies and argued that culture can also drive SME financing behavior.

Trade credit is a very important external source of financing for SMEs, giving goods instead of cash and the opportunity for the enterprise to pay its receivables according to the contract defined terms and time (Schwartz, 1974). Conditions of trade credit 
include the loan maturity and interest rate (Blazenko \& Vandezande, 2003; Bougheas, Mateut \& Mizen, 2009). Collateral may also be implemented contractually (Frank \& Maksimovic, 1998).

Trade credit advantages are in information acquisition visiting the buyer's premises more often, controlling the quality of the repayments, and permanent relationships with suppliers (Schwartz \& Whitcomb, 1979; Mian \& Smith, 1992; Ferris, 1981; Petersen \& Rajan, 1994).

\section{Materials and methods}

The hypothesis of the research was that the equity capital and trade credit, as the sources of finance of an agribusiness enterprise further invested in fixed and working capital, innovation and human resource development have the impact on the sustainability of its performances.

In this research model, three variables are included: two independent and one dependent. Independent variables are 1. Equity capital and trade credit as sources of finance of business operations (abbreviated, FS), and 2. The conditions of financing business operations of the company (abbreviated, as FC) defined as investments of these sources in a fix, working capital, human resource and innovations. The revenue of the companies is defined as a dependent variable (abbreviated as, CR), which, according to the impact of independent variables can increase, sustain or decrease.

Basing on the dataset of the empirical research provided in Serbia (second quarter of 2019) on the 132 enterprises from the agribusiness sector, privately owned, as the sample, the practices of the usage of equity capital and trade credit financing as the sources of finance has been explored. The aim was to elaborate the impact of these financing on the sustaining business performances of SMEs.

The methodology used includes survey method with a questionnaire in a collection of empirical research data, methods of descriptive statistical analysis, regression analysis and multiple linear correlations

Among 132 interviewed companies, 87 (0.65909) work in agribusiness production and 45 (0. 34091) in the supply chain sectors connected to the agribusiness, with the most activities on the domestic market, 105 enterprises from 132.

The level of the income of the enterprise in the previous year combined with the number of employees serves as two criteria for the SMEs according to the size. Data shows that the most of companies were small and micro, 53\%, medium-size, 38\%, and large $0,7 \%$ (which complies with the general structure of the enterprises in the agribusiness sector in Serbia.

So, 98 enterprises analyzed in the paper are privately owned $(0.74242)$. Directors and owners were most of the respondents of the survey: 44 owners (0. 33333), 59 directors (0.44697), 16 managers $(0.12121)$ and 13 consultants $(0.09848)$. These data show the representativeness of the sample, and valuable results. 
Table 1. Sample description.

\begin{tabular}{|l|l|r|r|}
\hline Indicators & Sub-Level & Count & Prob \\
\hline \multirow{5}{*}{ The company's income in 2019} & $<$ from $€ 100.000$ & 49 & 0.37121 \\
\cline { 2 - 4 } & $\begin{array}{l}\text { from 100.001 to } \\
€ 500.000\end{array}$ & 44 & 0.33333 \\
\cline { 2 - 4 } & $\begin{array}{l}\text { from 500.001 to } \\
€ 2.000 .000\end{array}$ & 27 & 0.20455 \\
\cline { 2 - 4 } & from $€ 2.000 .001$ & 12 & 0.09091 \\
\hline \multirow{2}{*}{ The origin of the income } & Domestic market & 105 & 0.79545 \\
\cline { 2 - 4 } & Foreign market & 27 & 0.20455 \\
\hline \multirow{3}{*}{$\begin{array}{l}\text { The conditions/purposes where the enterprise has } \\
\text { been invested in the equity capital and trade credit }\end{array}$} & $\begin{array}{l}\text { Fixed assets \& } \\
\text { working capital }\end{array}$ & 91 & 0.68940 \\
\cline { 2 - 4 } & $\begin{array}{l}\text { Innovation \& human } \\
\text { resource development }\end{array}$ & 41 & 0.31061 \\
\hline \multirow{2}{*}{$\begin{array}{l}\text { The sources of finance further investments impact on } \\
\text { company's financial performances in 2019 }\end{array}$} & Increase & 53 & 0.40152 \\
\cline { 2 - 4 } & Sustain & 66 & 0.50000 \\
\cline { 2 - 4 } & Decrease & 13 & 0.09848 \\
\hline
\end{tabular}

Studied selected sources of finance, equity and trade credit $68,9 \%$ companies further invested (here treated as conditions of finace) in the fiscal assets and working capital support, and $31 \%$ of the sample, in innovation and human resource development. This result outlines from the nature and time log of the resources, as well a from the basic reasons for borrowing (Slovin, Sushka \& Polonchek, 1993).

\section{Key findings}

In the created model of the research is given the opinions of the representatives of the enterprises from the agribusiness sector on the use and impact of the external sources of finance, equity and trading on their sustainability. The results elaborated through the interpretation of Person's correlation, are given in Figure 3.

The findings show that the directions of all possible links between independent and dependent variables are positive, which supports the positive correlation between these variables.

The large variability is between the conditions of financing (FC), and equity capital and trade credit as the sources of finance (FS), which amounts to 0.5701 and is medium strong. With $32.50 \%$ can be predicted the conditions of financing in coordination with the internal sources of finance.

The variation between the independent variables - sources of financing (FS) and independent variable - the conditions of financing (FC) amounted to 0.6246 and is medium strong.

The variation between the independent variables - conditions of financing (FC) and dependent variable amounted to 0.6528 and is medium strong. 
With $42.61 \%$ can be predicted the revenues of the company in coordination with the conditions of financing. The multiple correlation coefficient is 0.850 . Multiple determination of $\mathrm{r}$ is 0.722 . That means that $72.2 \%$ variability of independent variable FS and CF impacts the dependent CR variable, as it is displayed in Table 2.

Or, confirms the hypothesis of the research - that there is a positive impact of the internal sources and conditions of financing on the company's revenues/performances.

Table 2. Correlation of the research model

\begin{tabular}{|l|l|l|l|}
\hline & \multicolumn{1}{|c|}{ FS } & \multicolumn{1}{|c|}{ FC } & \multicolumn{1}{c|}{ CR } \\
\hline FS & 1.0000 & 0.5701 & 0.6246 \\
\hline FC & 0.5701 & 1.0000 & 0.6528 \\
\hline CR & 0.6246 & 0.6528 & 1.0000 \\
\hline
\end{tabular}

Because the score of statistical importance resulted to $\mathrm{p}<0.0001$, the hypothesis of the research H. $\mathrm{r}^{2}=0$ can be confirmed (Table 3 , ANOVA test).

Table 3. Test

\begin{tabular}{|l|r|r|r|r|}
\hline Source & DF & Sum of Squares & Mean Square & F Ratio \\
\hline Model & 2 & 31.961110 & 15.9806 & 70.0312 \\
\hline Error & 129 & 29.436774 & 0.2282 & Prob $>$ F \\
\hline C. Total & 131 & 61.397884 & & $<.0001^{*}$ \\
\hline
\end{tabular}

In Table 4, is specified the size of the contribution of independent variables: FS, FC in the prediction of dependent variable CR. According to the findings, it can be concluded that the most contribution to the company's performances make: 1. conditions of financing - their further usage in development purposes, with 0.43958

The factor of the variance increase is 1.4814044 .

The hypothesis of the research can be confirmed, as the trade credit and equity capital, and financial conditions of their further investment significantly affect the revenues of the company and its respective performances, the most in their sustainability.

Table 4. Coefficients for variables: FS, FC \& CR

\begin{tabular}{|l|r|r|r|r|r|l|}
\hline Term & Estimate & Std Error & t Ratio & Prob $>|t|$ & Std Beta & VIF \\
\hline Intercept & 1.646881 & 0.223448 & 7.37 & $<.0001^{*}$ & 0 & \\
\hline FS & 0.3289618 & 0.065264 & 5.04 & $<.0001^{*}$ & 0.37401 & 1.4814044 \\
\hline FC & 0.3717611 & 0.062753 & 5.92 & $<.0001^{*}$ & 0.43958 & 1.4814044 \\
\hline
\end{tabular}

The multiple regression equation is defined by further formulas $(1,2)$ :

$$
\mathrm{y}=1.646881+0.3289618 \mathrm{x}_{1}+0.3717611 \mathrm{x}_{2}
$$

or 
The company's revenues $=1.646881+0.3289618 \times$ Source of finance $+0.3717611 \times$ Conditions of finance

The regression equations for the formed model is illustrated in Figure 3.

Figure 3. Multiple regression equation for the model FS, FC \& CR

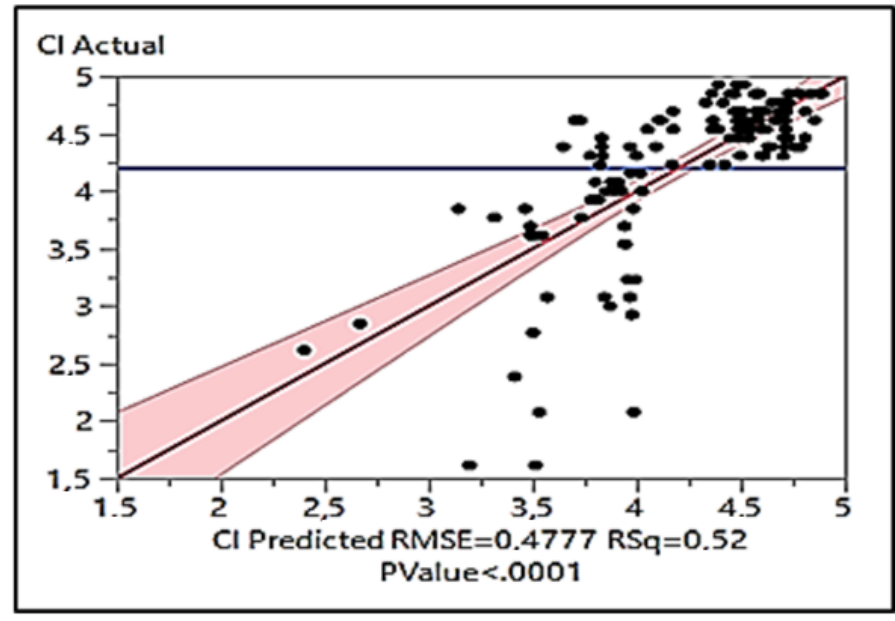

\section{Conclusions}

The practices on the usage, practice and terms of borrowing of the equity capital and the trade credit as external sources of financing for covering the corporate debt of SMEs have been researched. (Hill, Kelly \& Lockhart, 2012; 2013).

As such, the commercial relationship between buyers and suppliers, the characteristics of the traded good, providers of the equity capital play a crucial role in determining their existence, cost, and how the contracts are enforced. Being able to receive these financial sources helps SMEs from the sector manage their liquidity needs, sustain business, or further invest in innovation and human resources development (Eck, Engemann \& Schnitzer, 2015; Martínez-Sola, García-Teruel \& Martínez-Solano, 2013; Mateut, Mizen \& Ziane, 2015).

A major determinant of use by SMEs equity finance and trade financing is their availability. Equity financing is further known to be particularly important for SMEs in the agribusiness sector with high growth potential (Bodnaruk, O’Brien, \& Simonov, 2016). For SMEs, equity financing normally includes greater involvement of the financing provider in the firm compared to the bank lending that SMEs rely on as their main form of long-term financing (Fazzari \& Petersen, 1993)..

The conclusions are drawn from the literature and practices of SMEs, as well as from the opinion of the researched sample of the SMES on the impact of the trade credit and equity financing on the sustainability of the SMEs in the agribusiness sector in Serbia. The results of the empirical research imply a positive impact of the equity and trade 
credit financing on SMEs sustainability, giving the advantage of the conditions of the financing. That confirms the value of the research results for further work on the issues of the entrepreneurial rural financing issues (Smith, 1987; Menichini, 2011; Love \& Zaidi, 2010).

Financial stability governs the extent to which rural SMEs and entrepreneurs will trust their savings to financial institutions or actively participate in public markets (Wilner, 2000). Of particular relevance for SMEs, lower corporate gains taxes and quality of governance are identified in the literature as important drivers of greater preference of SMEs in the agribusiness sector in Serbia for, external equity and trade credit financing.

The limitations of the research are seen in not including the issues of the trust to be explored as a more relevant perspective on culture for SME attitudes towards equity and trade financing, as well as showing how trust is also linked to the institutional context (Uchida, Udell\& Watanabe, 2013).

Future development of the institutional, legal and sources of finance of the rural financial market in Serbia, as well as its the capacity building, would be of great importance for the growth and sustainability of the SMEs in the agribusiness sector. (Franks \& Sussman, 2005). It would have the positive influence on the increasing the private sector environment and cost-effectiveness of financial intermediaries in the rural financial market in Serbia.

\section{Conflict of interests}

The authors declare that there is no conflict of interest.

\section{Literature}

1. Ahmed, Z.U. (1989). Effective Costs of Rural Loans in Bangladesh. World Development, 17(3), 357-363. doi: https://doi.org/10.1016/0305-750X(89)90209-X

2. Besley, T. (1994). Savings, Credit and Insurance, in Jere Behrman and T.N. Srinivasan (eds.), Handbook of Development Economics, 3, 2123-2207. doi: https://doi. org/10.1016/S1573-4471(05)80008-7

3. Băncescu, I., Chivu, L., Preda, V., Puente-Ajovín, M., \& Ramos, A. (2019). Comparisons of log-normal mixture and Pareto tails, GB2 or log-normal body of Romania's all cities size distribution. Physica A: Statistical Mechanics and its Applications, 526, 121017. doi: https://doi.org/10.1016/j.physa.2019.04.253

4. Blazenko, G., \& Vandezande, K. (2003). Corporate holdings of finished goods inventories. Journal of Economics and Business, 55(3), 255 - 266. doi: https://doi. org/10.1016/S0148-6195(03)00023-7

5. Bougheas, S., Mateut, S., \& Mizen, P. (2009). Coroprate trade credit and inventories. Journal of Banking \& Finance, 33(2), 300-307. doi: https://doi.org/10.1016/j. jbankfin.2008.07.01

6. Bowles, S. (2003). Microeconomics: Behavior, Institutions, and Evolution. Princeton: Princeton, University Press. doi: https://doi.org/10.1515/9781400829316 
7. Clive, B., Srinivasan, T.N., \& Udry, C. (1997). Rationing, Spillover, and Interlinking in Credit Markets: The Case of Rural Punjab. Oxford Economic Papers, 49(4), 557-585. doi: https://doi.org/10.1093/oxfordjournals.oep.a028625

8. Conning, J., \& Udry, C. (2005). Rural Financial Markets in Developing Countries. Handbook of Agricultural Economics, 3, 2857-2908. doi: https://doi.org/10.1016/ S1574-0072(06)03056-8

9. Diamond, D. (1984). Financial intermediation and delegated monitoring. Review of Economic Studies, 51, 393-414. doi: https://doi.org/10.2307/2297430

10. Eck, K., Engemann, M., \& Schnitzer, M. (2015). How trade credits foster exporting. Review of World Economics, 151(1), 73-101. doi: https://doi.org/10.1007/ s10290-014-0203-8

11. Fazzari, S.M., \& Petersen, B. (1993). Working capital and fixed investment: new evidence on financing constraints. Rand Journal of Economics, 24, 328 - 342. doi: https://doi.org/10.2307/2555961

12. Ferris, J.S. (1981). A transactions Theory of trade credit use. Quurterly Journalof Economics, 96(2), 243-270.

13. Frank, M., \& Maksimovic, V. (1998). Trade Credit, Collateral, and Adverse Selection, University of Maryland.

14. Franks, J., \& Sussman, O. (2005). Financial Innovations and Corporate Insolvency. Journal of Financial Intermediation, 9(1), 65-96.

15. Garcia-Teruel, P.J., \& Martinez-Solano, P. (2007). Effects of working capital management on SME profitability. International Journal of Managerial Finance, 3, 164 - 177. doi: https://doi.org/10.1108/17439130710738718

16. Hart, O., \& Moore, J. (1991). A theory of debt based on the inalienability of human capital, Working paper, MIT.

17. Hawawini, G., Viallet, C., \& Vora, A. (1986). Industry influence on corporate working capital decisions. Sloan Management Review, 27, 15 - 24.

18. Hill, M., Kelly, W., \& Lockhart, B. (2013). Downstream Value of Upstream Finance. Financial Review, 48(4), 697-723. doi: https://doi.org/10.1111/fire.12021

19. Hill, M., Kelly, W., \& Lockhart, B. (2012). Shareholder Returns from Supplying Trade Credit. Financial Management 41(1), 255-280. doi: https://doi.org/10.1111/ j.1755-053x.2012.01198.x

20. Love, I., \& Zaidi, R. (2010). Trade Credit, Bank Credit and Financial Crisis. International Review of Finance, 10(1), 125-147. doi: https://doi.org/10.1111/j.14682443.2009.01100.x

21. Madestam, A. (2013). Informal Finance: A Theory of Moneylenders. Journal of Development Economics, 107, 157-174. doi: https://doi.org/10.1016/j.jdeveco.2013.11.001

22. Martínez-Sola, C., García-Teruel, P., \& Martínez-Solano, P. (2013). Trade credit policy and firm value. Accounting \& Finance, 53(3), 791-808. doi: https:/doi. org/10.1111/j.1467-629x.2012.00488.x 
23. Mateut, S., Mizen, P., \& Ziane, Y. (2015). Inventory composition and trade credit. International Review of Financial Analysis, 42, 434-446. doi: https://doi. org/10.1016/j.irfa.2015.09.008

24. Meltzer, A.H. (1960). Mercantile Credit, Monetary Policy and Size of Firms. Review of Economics and Statistics, 42, 429-437. doi: https://doi.org/10.2307/1925692

25. Mian, S., \& Smith. C.F. (1992). Accounts Receivable Management Policy: Theory and Evidence. The Journal of Finance, 47(1), 169-200. doi: https://doi. org/10.1111/j.1540-6261.1992.tb03982.x

26. Menichini, A.M. (2011). Inter-Firm Trade Finance in Times of Crisis. The World Economy, 34(10), 1788-1808. doi: https://doi.org/10.1111/j.14679701.2011.01390.x

27. More, D., \& Basu, P. (2013). Challenges of supply chain finance. Business Process Management Journal, 19(4), 624-647. doi: https://doi.org/10.1108/BPMJ-092012-0093

28. Murray, F., \& Maksimovic, V. (1998). Trade Credit, Collateral, and Adverse Selection, University of Maryland.

29. Myers, S.C., \& Rajan, R.G. (1998). The Paradox of Liquidity. Quarterly Journal of Economics, 113(3), 733-771. doi: https://doi.org/10.1162/003355398555739

30. Myers, S.C. (1977). Determinants of corporate borrowing. Journal of Financial Economics, 5(2), 147 - 175. doi: https://doi.org/10.1016/0304-405X(77)90015-0

31. Nilsen, J. (2002). Trade credit and the bank lending channel. Journal of Money, Credit and Banking, 34(1), 226-253. doi: https://doi.org/10.1353/mcb.2002.0032

32. Petersen, M., \& Rajan, R. (1997). Trade credit: theories and evidence. Review of Financial Studies, 10(3), 661 - 691. doi: https://doi.org/10.1093/rfs/10.3.661

33. Petersen, M., \& Rajan, R. (1995). The Effect of Credit Market Competition on Lending Relationships, Quarterly Joumlof Economics, 60, 407-444. doi: https:// doi.org/10.2307/2118445

34. Petersen, M., \& Rajan, R. (1994). The Benefits of Lending Relationships: Evidence from Small Business Data. Journal of Finance, 49(1), 3-37. doi: https://doi. org/10.1111/j.1540-6261.1994.tb04418.x

35. Ramey, V.A. (1992). The Source of Fluctuations in Money. Journal of Monetary Economics, 30(2), 171-93. doi: https://doi.org/10.1016/0304-3932(92)90059-B

36. Rajan, R., \& Zingales, L. (2003). Saving capitalism from the capitalists: unleashing the power of financial markets to create wealth and spread opportunity. $1^{\text {st }} \mathrm{ed}$. Book, Whole vols. New York: Crown Business.

37. Ray, D. (1998). Development economics, Princeton, N.J.: Princeton University Press.

38. Schmidt-Eisenlohr, T. (2013). Towards a theory of trade finance. Journal of International Economics, 91(1), 96-112. doi: https://doi.org/10.1016/j.jinteco.2013.04.005

39. Slovin, M.B., Myron, B.,Marie, E., Sushka, M., \& Polonchek, J. (1993). The value of bank durability: borrowers as bank stakeholders. Journal of Finance, 48, $247-$ 266. doi: https://doi.org/10.1111/j.1540-6261.1993.tb04708.x 
40. Smith, J. (1987). Trade Credit and Information Asymmetry. Journal of Finance, 42(4), 863-869. doi: https://doi.org/10.2307/2328295

41. Smith, K. (1980). Readings on the Management of Working Capital, West Publishing Co.

42. Schwartz, R.A., \& Whitcomb, S. (1979). The trade credit decision. In Bicksler, J.ed: Handbook of Financial Economics (North Holland Publishing Company).

43. Schwartz, R.A. (1974). An Economic Model of Trade Credit. Journal of Financial and Quantitative Analysis, 9(4), 643-657. doi: https://doi.org/10.2307/2329765

44. Uchida, H., Udell, G., \& Watanabe, W. (2013). Are trade creditors relationship lenders? Japan and the World Economy, 25-26, 24-38. doi: https://doi.org/10.1016/j. japwor.2013.01.002

45. Walker, D. (1991). An empirical analysis on financing the small firm. Advances in Small Business Finance, 47 - 61. doi: https://doi.org/10.1111/0022-1082.00203

46. Wilner, B.S. (2000). The exploitation of relationships in financial distress: the case of trade credit. Journal of Finance, 55, 153 - 178. doi: https://doi.org/10.1111/00221082.00203

47. Wu, Q.S. (2001). The determinant of working capital management policy and its impact on performance, National Science Council Project, Project No. NSC, 89. 